\title{
KEBIJAKAN GRAND DESIGN REFORMASI BIROKRASI 2010-2025 DALAM PENATAAN ORGANISASI DAN TATA LAKSANA
}

\author{
Agus Suryono \\ Fakultas Ilmu Administrasi Universitas Brawijaya \\ Email : agus_s@ub.ac.id
}

\begin{abstract}
Based on information collected empirically and normatively that the targets for the implementation of bureaucratic reform have not been achieved in the field of organization and governance at the institutional level of the bureaucracy in Malang City Government, partly due to: (a) Fatty organizational structures, overlapping both internal and external and not yet in accordance with the mandate of Perpres Number 81 of 2010 concerning the Grand Design of the National Bureaucratic Reform 2010-2025; (b) Standard Operating Procedures are convoluted so as to cause ineffective and inefficient public services. The objectives to be achieved in this study are: (1) To describe the causes of not achieving the target of implementing bureaucratic reform in the field of organizational structuring and management in Malang City Government (2) To describe and analyze and obtain efforts and models of acceleration in the implementation of bureaucratic reform in the field of organizational structuring and governance in the City Government of Malang. The method used is a qualitative approach, the location in this study is the Malang City Government especially the Law Bureau and the Malang City Organization. Sources of research data obtained through interviews and direct statements while those that are not directly indirect, can be in the form of notes, documents, manuals, and knowledge books. Data analysis in this study uses the interactive model of analysis of Miles and Huberman which was developed by Johnny Saldana (2013), which has three main components, among others: data reduction, data presentation, and drawing conclusions / verification. The results and conclusions obtained are the application of learning organizations in the framework of developing apparatus resources to improve performance in the Government of Malang City yet to be effective. This is due to several factors, including motivation and the ability of the apparatus to develop themselves is still low. The pattern of apparatus empowerment is considered not optimal. Learning infrastructure is inadequate, causing the process of getting information or knowledge to be hampered, cultural and relational learning has not been formed, collaboration and collegility have not grown well, there is no application of an award system that recognizes the achievements of organizational members, effective organizational structure structuring to accelerate the process of knowledge sharing, mental models, and shared vision. The application of learning

organizations that can work well must also be strengthened by information technology systems that can support the creation of a communication flow or information flow to increase the capacity of the government apparatus.
\end{abstract}

Article Histori:

Submited: $06 / 3 / 2020$

Editing: $23 / 04 / 2020$

Publish: 30/04/2020

Keyword: Grand design, Organization, City government of Malang 


\section{PENDAHULUAN}

Pada prinsipnya proses adaptasi organisasi terhadap lingkungannya merupakan kajian suatu organisasi sebagai sistem terbuka. Proses adaptasi ini dilakukan mulai dari hulu sampai ke hilir, yaitu mulai dari lingkungan input dalam rangka memperoleh sumber daya yang diperlukan sampai pada lingkungan output untuk menawarkan segalam macam produk yang dihasilkan. Pendekatan organisasi sistem terbuka menjadi era baru dalam kajian teori organisasi. Konsep adaptasi seperti ini sesunggungnya diadopsi dari ilmu biologi yang menjelaskan reaksi dari suatu organisme untuk dapat bertahan terhadap tuntutan dan tekanan perubahan lingkungannya. Dengan demikian pengertian adaptasi dapat dijelaskan sebagai suatu tindakan organisasi untuk melakukan perubahan struktur dalam rangka memelihara keadaan untuk mencari keseimbangan terhadap perubahan lingkungan yang dinamis, sehingga akan membentuk suatu komposisi struktur lingkungan yang saling bersinergis.

Tampilan birokrasi yang gemuk akan menghabiskan banyak sumberdaya, pemerintah sudah menggagas melalui Peraturan Presiden Nomor 81 Tahun 2010 tentang Grand Design Reformasi Birokrasi Perpes tersebut mencakup 3 (tiga) program antara lain yaitu makro, meso dan mikro. Pada tahun 2011, seluruh kementerian dan lembaga serta pemerintah daerah diharuskan melaksanakan reformasi birokrasi yang mencakup 8 (delapan) area perubahan, yaitu:

1. Organisasi dengan output yaitu organisasi yang tepat fungsi dan tepat ukuran

2. Tata laksana dengan output sistem, proses dan prosedur kerja yang jelas, efektif dan efesien, terukur dan sesuai dengan prinsip good governance.
3. Peraturan perundang-undangan dengan output regulasi yang tertib, tidak tumpang tindih dan kondusif.

4. Pengawasan, dengan output peningkatan kapasitas dan akuntabilitas kinerja birokrasi.

5. Akuntabilitas, meningkatnya kapasitas dan akuntabilitas kinerja birokrasi.

6. Pelayanan publik, dengan output pelayanan prima sesuai dengan kebutuhan masyarakat.

7. Pola pikir dan budaya kerja, dengan target biokrasi yang memiliki integritas dan kinerja yang tinggi.

Pelaksanaan dari reformasi birokrasi yang mencakup 8 (delapan) area perubahan tersebut diatas, diharapkan mampu ditransformasikan kedalam 9 (sembilan) program dan kegiatan tingkat mikro di kementerian dan lembaga, antara lain: (1) Manajemen perubahan, (2) Penataan peraturan perundang-undangan,

Penataan dan penguatan organisasi, (4) Penataan tata laksana, (5) Penataan sistem manajemen SDM aparatur, (6) Penguatan pengawasan, (7) Penguatan akuntabilitas Kerja, (8) Peningkatan kualitas pelayanan publik, (9) Monitoring, evaluasi dan pelaporan.

Dalam hal ini reformasi birokrasi dilakukan untuk mencapai good governance. Demikian pula, reformasi birokrasi di Indonesia menempatkan pentingnya rasionalisasi birokrasi untuk menciptakan efesiensi, efektifitas, dan produktifitas melalui pembagian kerja hirarkikal dan horizontal yang seimbang, diukur dengan rasio antara volume atau beban tugas dengan jumlah sumber daya disertai tata kerja formalistik dan pengawasan yang ketat.

Tujuan kebijakan reformasi birokrasi di Indonesia adalah untuk membangun sikap, profil dan perilaku aparatur negara yang memiliki integritas, 2

P-JIAP: Vol. 5 (1) 2020; Suryono

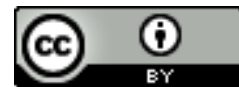


produktivitas, dan bertanggung jawab serta memiliki kemampuan memberikan pelayanan yang prima melalui perubahan pola pikir (mind set) dan budaya kerja (culture set) dalam sistem manajemen pemerintahan. Salah satu tuntutan dari reformasi birokrasi adalah birokrasi yang akuntabel dan bertanggung jawab atas setiap proses kinerja atau hasil akhir dari program maupun kegiatan yang terkait dengan pengelolaan dan pengendalian sumber daya dan pelaksanaan kebijakan untuk mencapai tujuan. Dilakukannya penataan organisasi itu agar dapat menentukan kinerja organisasi pemerintah dalam melaksanakan tugas dan fungsinya sebagai penyelenggara pelayanan publik, pengadaan fasilitas umum, dan penyelenggaraan regulasi. Hal ini terutama karena penataan organisasi terkait dengan bagaimana struktur organisasi disusun, tugas dan fungsi dirumuskan, serta bagaimana tumpang tindih, duplikasi dan jumlah (size) organisasi yang dikelola akan menentukan seberapa efektif dan efesien sebuah organisasi. Efisiensi tidak akan dapat tercapai pada organisasi yang memiliki duplikasi tugas dan fungsi yang tidak jelas.

Mengingat pentingnya struktur dan tata kerja terhadap kinerja organisasi tersebut, tentu diharapkan bahwa penataan organisasi pemerintah dapat dilakukan dengan sebaik-baiknya. Berbagai aspek krusial dalam penataan organisasi pemerintah, seperti peraturan perundangundangan yang mengaturnya, prinsipprinsip pengorganisasian, kapasitas organisasi itu sendiri, dan responsifitas terhadap perubahan lingkungan strategis yang semakin kompleks seperti tekanan publik, politik, organisasi internasional, krisis ekonomi, lingkungan, ideologi, sosial, dan permasalahan krusial lainnya tidak bisa diabaikan. Dengan demikian, penataan organisasi pemerintah bukanlah hal yang mudah dan sederhana mengingat di era globalisasi ini, kompleksitas tiap-tiap aspek tersebut kian tinggi.

Hampir lima tahun sudah gagasan Reformasi Birokrasi (RB) disosialisasikan oleh Kementerian Pendayagunaan Aparatur Negara dan Reformasi Birokrasi untuk segera diimplementasikan. Namun proses implementasi dari gagasan RB itu, belum menunjukkan perkembangan yang menggembirakan. Bahkan ketika gagasan itu diperkuat dengan Peraturan Presiden No. 81 tahun 2010 yang menetapkan tentang Grand Design dan Road Map Reformasi Birokrasi, dalam prakteknya, pelaksanaan reformasi birokrasi tetap belum menunjukkan adanya percepatan dalam implementasinya.

Sebagian dari masyarakat, terutama mereka yang selama ini memberikan perhatian khusus pada upaya implementasi reformasi birokrasi, beranggapan bahwa reformasi birokrasi yang dicanangkan pemerintah "mandek" dalam pelaksanaannya, "kemandekan" itu terindikasi dari masih "gemuknya" organisasi. Hal ini terlihat saat ini bahwa tidak ada indikasi pemerintah untuk merestrukturisasi organisasi, hal yang terjadi justru sebaliknya menggemukkan birokrasi. Faktanya jumlah lembaga bertambah dalam bentuk komisi, badan dan lembaga non kementerian (baca, Kompas, 2013)

Dari segi penataan ketatalaksanaan, perubahan ketatalaksanaan ditujukan untuk melakukan penataan sistem, mekenisme atau prosedur di instansi pemerintah yang lebih efektif dan efisien. Salah satu bentuk penataan tata laksana yaitu dilakukan penyusunan dan implementasi Standar Operasional Prosedur Administrasi Pemerintahan (selanjutnya disebut dengan SOP AP).

Oleh karena itu, berdasarkan uraian diatas secara empiris dan normatif bahwa 
belum tercapainya target pelaksanaan reformasi birokrasi di bidang organisasi dan tata laksana pada tingkat kelembagaan birokrasi ini, antara lain disebabkan: (a) Struktur organisasi yang gemuk, tumpang tindih baik internal maupun eksternal dan belum sesuai dengan amanat Perpres Nomor 81 Tahun 2010 tentang Grand Design Reformasi Birokrasi Nasional 20102025; (b) Standar Operasional Prosedur yang berbelit-belit sehingga menyebabkan pelayanan publik yang tidak efektif dan efesien.

Adapun tujuan yang ingin dicapai dalam penelitian ini adalah: (1) Untuk mendeskripsikan penyebab tidak tercapainya target implementasi kebijakan reformasi birokrasi bidang penataan organisasi dan ketatalaksanaan di Pemerintahan Kota Malang (2) Untuk mendeskripsikan dan menganalisis serta memperoleh upaya dan model percepatan dalam pelaksanaan reformasi birokrasi bidang penataan organisasi dan tata laksana di Pemerintahan Kota Malang.

\section{METODE PENELITIAN}

Dalam penelitian ini penulis menggunakan pendekatan kualitatif karena dapat digunakan untuk mengungkap dan memahami sesuatu dibalik fenomena yang sedikitpun belum diketahui. Peneliti melibatkan diri secara mendalam untuk bertanya (apakah, mengapa, bagaimana), dan kemudian mendengar,mencatat, mengamati, terlibat, menghayati dan mengambil inferensi dari obyek di lapangan dan kemudian melakukan analisi secara kualitatif atas keseluruhan data.

Fokus penelitian diarahkan sebagai tahap kesinambungan dari rumusan masalah serta tinjauan pustaka untuk membantu menjawab dan menganalisis masalah. Adapun yang menjadi fokus dalam penelitian ini adalah :
1. Penyebab tidak tercapainya target implementasi reformasi birokrasi bidang penataan organisasi dan tata laksana di Pemerintahan Kota Malang, hal ini dapat diamati dari:

a. Komunikasi terkait dengan hal-hal yang sistematis diantara pelaksana atau aktor kebijakan dan dapat dilihat dari pelaksaanan grand design dan road map penataan organisasi dan tata laksana di Pemerintahan Kota Malang

b. Disposisi, terkait dengan kewenangan para aktor pelaksana dalam mendukung dan melaksanakan program penataan organisasi dan tata laksana Mekanisme, Sistem, Proses, dan Prosedur kerja di Pemerintahan Kota Malang

c. Sumber daya, dalam kaitanya dengan sumber daya manusia dan anggaran dalam program penataan organisasi dan tata laksana

d. Struktur Birokrasi, dapat dilihat dari tugas, pokok dan fungsi serta mekanisme atau standar operasional di Pemerintahan Kota Malang.

2. Upaya percepatan pelaksanaan reformasi birokrasi bidang penataan organisasi dan tatalaksana di Pemerintahan Kota Malang, antara lain :

a. Desain organisasi Kementerian Kelautan dan Perikanan tepat fungsi tepat ukuran melalui Analisa Beban Kerja.

b. Syarat dan metode penataan organisasi

c. Sistem, Proses, dan Prosedur kerja yang jelas, efektif, efisien, terukur dan sesuai dengan prinsip-prinsip good governance

d. Program percepatan/Quick Wins terhadap Standar Operasional Prosedur.

Adapun yang menjadi lokasi dalam penelitian ini adalah Pemerintahan Kota Malang. Dari lokasi ini, peneliti menetapkan situs penelitian yang merupakan tempat dimana peneliti dapat menangkap keadaan yang sebenarnya dari obyek yang diteliti. 
Dalam upaya tersebut, peneliti mengawalinya dari Biro Hukum dan Organisasi Kota Malang; Disinilah pusat harmonisasi kegiatan reformasi birokrasi bidang tata laksana Pemerintahan Kota Malang.

Sumber data penelitian diperoleh melalui wawancara maupun pernyataan langsung dengan pihak-pihak yang terkait antara lain berasal dari Biro Hukum dan Organisasi Pemerintahan Kota Malang. Disamping, bahan-bahan dan informasi lain untuk mendukung data primer, dan bahan dokumen serta informasi ini diperoleh secara tidak langsung, bisa berupa catatan atau informasi yang berupa dokumen atau buku-buku pedoman atau buku pengetahuan serta informasi yang berkaitan dengan obyek penelitian, bahan-bahan, dokumen-dokumen atau arsip-arsip yang terkait dengan penelitian ini. Antara lain, Peraturan Presiden Nomor 81 tahun 2010 tentang Grand Design Reformasi Birokrasi Nasional 2010-2025, Peraturan Menteri PAN dan RB nomor 20 tahun 2010 tentang Road Map Reformasi Birokrasi 2010-2014 dan Peraturan Menteri PAN dan RB nomor 11 tahun 2011 tentang Kriteria dan Ukuran Keberhasilan Reformasi Birokrasi.

Adapun langkah-langkah analisis data penelitian ini menggunakan model analisis interaktif (interactive model of analysis) Miles dan Huberman yang telah di kembangkan oleh Johnny Saldana (2013), yang memiliki tiga komponen utama antara lain : reduksi data, penyajian data, dan menarik suatu kesimpulan/ verifikasi.

\section{HASIL DAN PEMBAHASAN}

\section{A. Visi, dan Misi Kota Malang}

Rencana Pembangunan Jangka Menengah Daerah adalah dokumen perencanaan untuk periode 5 (lima) tahun. Rencana Pembangunan Jangka Menengah Satuan Kerja Perangkat Daerah disebut Renstra-SKPD untuk periode 5 (lima) tahun.
SKPD menyusun renstra disesuaikan dengan tugas pokok dan fungsinya dengan berpedoman pada RPJMD. Sedangkan Rencana Pembangunan Tahunan Daerah, yang selanjutnya disebut Rencana Kerja Pemerintah Daerah (RKPD) adalah dokumen perencanaan daerah untuk periode satu tahun. RKPD merupakan visi dan misi dalam RPJMD. RPJP diimplementasikan ke dalam RPJMD 5 tahun pertama, kedua hingga 5 tahun ke empat. Sedangkan RPJM daerah diimplementasikan dalam RKPD tahunan hingga tahun ke lima.

Berdasarkan RPJPD itu maka masing-masing satuan kerja perangkat daerah berkewajiban menyusun visi dan misi sesuai dengan tugas pokok dan fungsinya, dengan ketentuan tetap mengacu pada visi dan misi Kota Malang. Visi Kota Malang 20 Tahun ke depan adalah berdasarkan "Terwujudnya Kota Malang sebagai Kota Mandiri, Pendidikan yang Berkualitas, Berbudaya, Berwawasan Lingkungan Menuju Masyarakat Sejahtera'"'" Mandiri artinya bahwa ke depan Kota Malang diharapkan mampu membiayai sendiri seluruh penyelengaraan pemerintahan dan pelaksanaan pembangunan dengan memanfaatkan sumber daya lokal (SDA, Potensi Daerah SDM yang dimiliki). Berbudaya bahwa pelaksanaan fungsi pemerintahan Kota Malang dalam mencapai visi harus mengedepankan nilai-nilai Ke-Tuhanan, kemanusiaan, dan nilai-nilai kehidupan sosial kemasyarakatan (kearifan lokal) melalui pengembangan pendidikan untuk mengantisipasi perkembangan Kota Malang menuju kota Metropolis. Pemahaman ini lebih dititik beratkan pada pencapaian kesadaran emosional, kecerdasan spiritual, dan intelektual. Sejahtera mengandung arti bahwa pelaksanaan otonomi daerah diarahkan untuk peningkatan pelayanan publik yakni terwujudnya kesejahteraan 
masyarakat seluruhnya, baik materiil maupun spiritual. Sedangkan berwawasan lingkungan adalah pelaksanaan pemerintahan daerah dalam upaya tetap menjaga kelestarian alam dan kualitas lingkungan serta pemukiman.

\section{B. Sumberdaya Aparatur Pemerintah Kota Malang}

Sumber daya aparatur pemerintah merupakan salah satu unsur-unsur manajemen yang sangat menentukan keberhasilan organisasi dalam mewujudkan visi dan misinya. Sumber daya aparatur pemerintah (pegawai) bukan hanya dilihat dari aspek kuantitas melainkan juga diikuti dimensi kualitasnya. Ini sangat penting mengingat kebijakan desentralisasi memberikan deskresi yang luas melakukan kreasi guna meningkatkan pelayanan publik.

Penyelenggaraan pemerintahan dan pembangunan di Pemerintah Kota Malang didukung oleh SDM aparatur yang berjumlah 9.949 orang, yang terdiri dari PNS non guru, guru, paramedis. Jumlah Pegawai Negeri Sipil Daerah tersebut untuk melayani masyarakat Kota Malang yang berjumlah 840.084 orang. Artinya setiap pegawai dapat melayani sekitar 85 orang masyarakat. Adapun komposisi PNS dapat dirinci sebagai berikut :

Tabel 1.

Komposisi SDM Aparatur Kota Malang berdasarkan golongan, pendidikan, eselon, jenis kelamin, dan agama.

\begin{tabular}{|c|c|c|c|c|c|}
\hline \multicolumn{6}{|c|}{ Komposisi PNS berdasarkan } \\
\hline \multirow{3}{*}{$\begin{array}{c}\text { Jenis } \\
\text { Kelamin }\end{array}$} & LK & 5.170 & \multirow[t]{6}{*}{ Agama } & Islam & 9.112 \\
\hline & PR & 4.779 & & Kristen & 510 \\
\hline & Jml & 9.949 & & Khatolik & 253 \\
\hline \multirow[t]{5}{*}{ Golongan } & IV & 2.782 & & Hindu & 68 \\
\hline & III & 3.801 & & Budha & 6 \\
\hline & II & 2.177 & & Jml & 9.949 \\
\hline & I & 1.189 & \multirow[t]{10}{*}{ Pendidikan } & S3 & 3 \\
\hline & Jml & 9.949 & & S2 & 315 \\
\hline \multirow[t]{8}{*}{ Eselon } & II.a & 1 & & S1 & 4.386 \\
\hline & II.b & 31 & & D.III & 681 \\
\hline & III.a & 46 & & D.II & 655 \\
\hline & III.b & 93 & & SLTA & 2.326 \\
\hline & IV.a & 451 & & SMP & 813 \\
\hline & IV.b & 361 & & SD & 770 \\
\hline & V.a & 34 & & Jml & 9.949 \\
\hline & Jml & 1.017 & & & \\
\hline
\end{tabular}

Sumber data : Badan Kepegawaian Daerah Kota Malang, 2017/2018

Data Pegawai Negeri Sipil pada Pemerintah Kota Malang di atas di susun berdasarkan jenis kelamin, golongan, eselon, agama, dan tingkat pendidikan. Namun yang berkenaan langsung dengan organisasi pembelajaran (organization learning) adalah tingkat pendidikan pegawai. PNS dengan tingkat pendidikan S1 memiliki angka yang cukup besar yakni
(44,08\%), dan kemudian disusul pendidikan SLTA (23,37\%). Banyaknya pendidikan S1 ini disebabkan penerimaan pegawai beberapa tahun terakhir ini tidak menerima pendidikan SLTA ke bawah. Selain itu, adanya kenaikan pangkat penyesuaian ijazah S1 bagi pegawai pendidikan SLTA.

Data yang berkenaan dengan tingkat pendidikan memiliki dampak terhadap 
organisasi pembelajar, sebab sejalan dengan perkembangan globalisasi, serta peningkatan tuntutan masyarakat, maka pendidikan Pegawai Negeri Sipil perlu ditingkatkan dengan mendorong para pegawai untuk melanjutkan pendidikan. Pendidikan merupakan bagian yang tidak dipisahkan dari usaha organisasi untuk membelajarkan anggotanya, dengan tujuan mempersiapkan aparatur pemerintah yang memiliki kemampuan dan perilaku yang positif dalam rangka pengembangan tugastugas kemanusiaan.

Berkaitan dengan jumlah pegawai, di bawah ini akan dirincikan berdasarkan unit kerjanya yang tersebar di lingkup Pemerintah Kota Malang sebagai berikut :

Tabel 2.

Jumlah PNS/ASN berdasarkan unit kerja s/d Desember 2018

\begin{tabular}{|c|c|c|c|c|c|}
\hline No & Unit Kerja & Jml & No & Unit kerja & Jml \\
\hline 1 & Inspektorat & 39 & 20 & Dinas keternagakerjaan \& sosial & 52 \\
\hline 2 & Bappeda & 36 & 21 & Dinas pendapatan & 118 \\
\hline 3 & Badan Kepegawaian Daerah & 48 & 22 & $\begin{array}{llll}\begin{array}{l}\text { D.Koperasi } \\
\text { menengah }\end{array} & \& & \text { usaha } & \text { kecil } \\
\end{array}$ & 29 \\
\hline 4 & Badan KB dan Pem. Masyarakat & 105 & 23 & D.kependud. \& pencatatan sipil & 61 \\
\hline 5 & $\begin{array}{l}\text { Badan kesatuan bangsa dan } \\
\text { politik }\end{array}$ & 26 & 24 & Kantor perpus.Umum \& Arsip & 41 \\
\hline 6 & Badan lingkungan hidup & 33 & 25 & Satpol PP. & 182 \\
\hline 7 & Badan peijinan terpadu & 52 & 26 & Sekretariat daerah & 306 \\
\hline 8 & Dinas pekerjaan umum & 152 & 27 & Staf ahli & 3 \\
\hline 9 & Dinas pasar & 297 & 28 & Sekretariat DPRD & 52 \\
\hline 10 & $\begin{array}{l}\text { Dinas kebersihan dan } \\
\text { pertamanan }\end{array}$ & 1.102 & 29 & Sekretariat KPUD & 9 \\
\hline 11 & Dinas perumahan & 42 & 30 & Kecamatan Klojen & 131 \\
\hline 12 & Dinas kepemudaan dan olah raga & 83 & 31 & Kecamatan Blimbing & 142 \\
\hline 13 & Dinas kesehatan & 595 & 32 & Kecamatan Lowokwaru & 147 \\
\hline 14 & Dinas pendidikan & 162 & 33 & Kecamatan sukun & 151 \\
\hline 15 & $\begin{array}{lll}\begin{array}{l}\text { Dinas } \\
\text { pariwisata }\end{array} & \text { dan } \\
\end{array}$ & 64 & 34 & Kecamatan kendungkandang & 155 \\
\hline 16 & Dinas pertanian & 72 & 35 & Taman Kanak-Kanak & 110 \\
\hline 17 & $\begin{array}{l}\text { Dinas komunikasi } \\
\text { informatika }\end{array}$ & 35 & 36 & SD & 2.284 \\
\hline 18 & Dinas perhubungan & 328 & 37 & SLTP & 1.220 \\
\hline \multirow[t]{2}{*}{19} & \multirow{2}{*}{$\begin{array}{l}\text { Dinas perindustrian \& } \\
\text { perdagangan }\end{array}$} & \multirow[t]{2}{*}{38} & 38 & SLTA & 1.341 \\
\hline & & & 39 & Pendidikan lain-lain & 106 \\
\hline & \multicolumn{4}{|c|}{ Jumlah seluruhnya } & 9.949 \\
\hline
\end{tabular}

Sumber data : BKD Kota Malang, 2018.

Data di atas menunjukkan jumlah PNS yang tersebar pada dinas/instansi Pemerintah Kota Malang berjumlah 9.949 orang dengan komposisi terbanyak berada pada unit kerja pendidikan yakni SLTA, SLTP, dan SD. Sementara pada tataran dinas adalah dinas kebersihan dan pertamanan. Banyaknya PNS pada tingkat pendidikan karena banyak lembaga pendidikan yang ada di Kota Malang.

\section{Pengembangan Sumberdaya Aparatur Pemkot Malang}

Pengembangan sumber daya aparatur pada Pemerintah Kota Malang dilakukan melalui berbagai strategi, antara lain pendidikan formal, pelatihan, mutasi, 
kegiatan pengasahan dalam menulis karya tulis, dan membuat telaahan staf. Strategi pendidikan adalah proses yang dilakukan secara sadar dan terprogram, sistematis, dan terarah pada tujuan yang jelas. Upaya pendidikan dalam rangka memperoleh pengetahuan, dan pengetahuan yang sudah diperoleh mesti ditandai dengan perbaikanperbaikan dalam kehidupan termasuk kehidupan organisasi, agar dapat menyadarkan diri manusia dalam memberikan pelayanan publik yang lebih baik. Dengan pengetahuan yang cukup akan dapat menunjang penguasaan pegawai dalam melaksanaan tugasnya dengan baik.

Diklat kepemimpinan bertujuan untuk memberikan peningkatan pola pikir, kemampuan serta penguasaan dan keterampilan pelaksanaan pekerjaan, pengelolaan kegiatan dan program secara efektif dan efisien. Badan Kepagawaian Pemerintah Kota Malang hanya menyelenggarakan ujian penyesuaian ijazah, dan ujian dinas tingkat I dan II. Diklatpim, diklat fungsional, diklat teknis maupun diklat prajabatan Calon PNS diselenggarakan oleh Badan Diklat Provinsi Jawa Timur atau badan/lembaga lain yang terakreditasi, karena BKD Pemerintah Kota Malang tidak memiliki Badan Diklat.

Kegiatan pendidikan dan pelatihan kepemimpinan tersebut ditunjang oleh APBD Kota Malang. Untuk mengetahui rincian anggaran pendidikan dan pelatihan dalam dua tahun terakhir:

Tabel 3.

APBD Kota Malang untuk diklat struktural, teknis fungsional, ujian kenaikan pangkat/dinas 2018-2019

\begin{tabular}{|c|c|c|c|c|}
\hline \multirow[t]{2}{*}{ No } & \multirow[t]{2}{*}{ Jenis kegiatan } & \multicolumn{2}{|c|}{ Tahun } & \multirow[t]{2}{*}{ Jumlah } \\
\hline & & 2018 & 2019 & \\
\hline 1 & Diklat struktural & $231.015 .000,-$ & - & 231.015.000,- \\
\hline 2 & Diklat teknis fungsional & $556.625 .000,-$ & $51.450 .000,-$ & $608.075 .000,-$ \\
\hline 3 & Diklatpim IV & $294.800 .000,-$ & - & $294.800 .000,-$ \\
\hline 4 & Diklat Fungsional & 157.625.000,- & - & $157.625 .000,-$ \\
\hline 5 & Prajabatan & 1.689.660.000,- & 1.379.400.000,- & 3.069.060.000,- \\
\hline 6 & $\begin{array}{l}\text { Bintek pengadaan barang dan jasa } \\
\text { pemerintah }\end{array}$ & 86.716.700,- & - & $86.716 .700,-$ \\
\hline 7 & Ujian kenaikan pangkat dan ujian dinas & $28.835 .220,-$ & $33.205 .500,-$ & $620.040 .720,-$ \\
\hline 8 & Outbound jajaran eksekutif & $398.810 .000,-$ & - & $398.810 .000,-$ \\
\hline & Jumlah & 3.045.276.000,- & 1.464.055.500 - & 5.067.331.420,- \\
\hline
\end{tabular}

Sumber data : BKD Kota Malang, 2018/2019.

Jumlah anggaran untuk pengembangan SDM aparatur Pemerintah Kota Malang terdapat perbedaan cukup jauh pertahunnya. Perbedaan ini disebabkan beberapa mata diklat struktural, diklat fungsional, outbound jajaran eksekuti di tahun 2009 tidak ada, karena Pemerintah Kota Malang lebih melaksanakan diklat teknis fungsional. Kebijakan melaksanakan diklat teknis fungsional dirasa sangat tepat mengingat perbaikan keterampilan yang langsung berkaitan dengan tugas-tugas riil saat ini, sehingga porsi jenis diklat ini begitu diperhatikan dan diperbanyak.

Dalam hal pengembangan SDM ini, Pemerintah Kota Malang menyelenggarakan dengan pola kemitraan dengan lembaga pemerintah,lembaga pendidikan terakreditasi, maupun pihak swasta yang memenuhi syarat. Ini dilakukan mengingat Pemerintah Kota Malang belum memiliki Badan Diklat 
sendiri, sehingga berbagai diklat itu dilaksanakan dengan pola kemitraan guna menjamin mutu yang dihasilkannya. Untuk menyelenggarakan diklat prajabatan terhadap Calon Pegawai Negeri Sipil, diklatpim, diklat teknis fungsional, dilaksanakan dengan pola kemitraan dengan Badan Kediklatan Provinsi Jawa Timur. Penyelenggara diklatpim juga dilaksanakan oleh Lembaga Administrasi Negara. Demikian juga diklat teknis fungsional diselenggarakan oleh Lembaga/Perguruan Tinggi yang sudah diakui kualitasnya, seperti Universitas Brawijaya, Lembaga Pengabdian Masyarakat Universitas Brawijaya, Bappenas, Lembaga Pendidikan Manajemen. Penyelenggaraan diklat dengan pola kemitraan dalam arti Pemerintah Kota Malang menyediakan anggaran dan mengirimkan peserta diklat.

Tabel 4.

Jumlah pegawai yang telah mengikuti diklat teknis fungsional Tahun 2018

\begin{tabular}{|c|c|c|c|c|}
\hline No & Jenis Diklat & Jml & Status & Penyelenggara \\
\hline 1 & Bintek Akuntansi Keuangan Daerah & 43 & \multirow[t]{4}{*}{$\begin{array}{l}\text { Pjbt struktural } \\
\text { dan staf }\end{array}$} & $\begin{array}{l}\text { Pusat Kajian Keuangan Negara } \\
\text { dan Daerah, bekerjasama dengan } \\
\text { UB }\end{array}$ \\
\hline 2 & Manajemen kependudukan & 57 & & Indonesia Multi Management \\
\hline 3 & $\begin{array}{l}\text { Tata Naskah dinas bagi aparatur } \\
\text { kelurahan (Angkatan I) }\end{array}$ & 43 & & \multirow{3}{*}{$\begin{array}{l}\text { RCCP Fakultas Ilmu Administrasi } \\
\text { UB }\end{array}$} \\
\hline 4 & $\begin{array}{l}\text { Tata Naskah dinas bagi aparatur } \\
\text { kelurahan (Angkatan II) }\end{array}$ & 57 & & \\
\hline 5 & Manajemen Aparatur Kelurahan & 57 & Pjb strktural & \\
\hline 6 & $\begin{array}{l}\text { Penulisan karya ilmiah bagi pejabat } \\
\text { fungsional (Angkatan I) }\end{array}$ & 50 & \multirow[t]{2}{*}{$\begin{array}{l}\text { Pjb struktural } \\
\text { dan staf }\end{array}$} & \multirow{2}{*}{$\begin{array}{lcr}\text { Lembaga } & \text { Pengabdian } & \text { Kepada } \\
\text { Masyarakat } & \text { Universitas } & \text { Negeri } \\
\text { Malang } & & \\
\end{array}$} \\
\hline 7 & $\begin{array}{l}\text { Penulisan karya ilmiah bagi pejabat } \\
\text { fungsional (Angkatan II) }\end{array}$ & 49 & & \\
\hline 8 & $\begin{array}{l}\text { Pelatihan touble Shooting, jaringan dan } \\
\text { Instalasi (Angkatan I) }\end{array}$ & 43 & Pjb dan staf & \multirow[t]{2}{*}{$\begin{array}{l}\text { Lembaga Pendidikan Manajemen } \\
\text { Bisnis dan Komputer (LPMBK) }\end{array}$} \\
\hline 9 & $\begin{array}{l}\text { Pelatihan touble Shooting, jaringan dan } \\
\text { Instalasi (Angkatan II) }\end{array}$ & 57 & Pjb dan staf & \\
\hline 10 & Diklat juru sita & 6 & Staf & Balai Diklat Keu IV Malang \\
\hline 111 & Diklat total image for supervisor & 1 & & \multirow[t]{2}{*}{ Badan Diklat Prov.Jawa Timur } \\
\hline 12 & $\begin{array}{l}\text { Pengembang diri pemberdayaan } \\
\text { potensi diri }\end{array}$ & 1 & Staf BKD & \\
\hline 13 & Pelatihan pengawas obat hewan & 1 & Staf & \multirow[t]{2}{*}{ Dinas Peternakan Provinsi Jatim } \\
\hline 14 & Pelatihan inseminasi buatan & 1 & Penyuluh & \\
\hline 15 & Diklat pembantu PPAT & 1 & Pjb struktural & Badan Diklat Provinsi Jatim \\
\hline 16 & $\begin{array}{l}\text { Pembinaan teknis calon } \\
\text { sementara Angkat IV }\end{array}$ & 1 & Camat & $\begin{array}{lcl}\text { Kanwil Badan } & \text { pertanahan } \\
\text { Nasional Prov. Jatim } & \end{array}$ \\
\hline 17 & Kursus keuangan daerah & 1 & Staf & Fakultas Ekonomi UB \\
\hline 18 & Basic English for Academic Purpose & 1 & Pjb struktural & BAPPENAS \\
\hline 19 & Diklat perencaan pembangunan & 1 & Pjb Struktural & BAPPENAS \\
\hline 20 & Diklat Penyuluh KB & 1 & Penyuluh KB & \\
\hline 21 & Diklat English For Tourism & 1 & Staf & \\
\hline 22 & Evaluasi dampak diklat tahap II & 1 & Staf & \\
\hline 23 & $\begin{array}{l}\text { Peningkatan } \\
\text { pengarusutaman Gender }\end{array}$ & 1 & Ka UPT KB & \\
\hline 24 & Pengembangan IESQ Angkatan IV & 1 & Pjb struktural & \\
\hline
\end{tabular}




\begin{tabular}{|c|c|c|c|c|}
\hline No & Jenis Diklat & Jml & Status & Penyelenggara \\
\hline 25 & Manajemen Angkutan Umum & 1 & Pjb struktural & \multirow{7}{*}{ Badan Diklat Prov. Jatim } \\
\hline 26 & Peran kepemimpinan & 1 & Staf & \\
\hline 27 & Pemberdayaan Otak Angkatan II & 1 & Staf & \\
\hline 28 & $\begin{array}{l}\text { Diklat transformasi kebijakan pemda } \\
\text { unuk pembangunan \&pelayanan } \\
\text { masyarakat Angkatan I }\end{array}$ & 1 & Camat & \\
\hline 29 & $\begin{array}{l}\text { Metode peningkatan kapasitas Guru } \\
\text { pemandu mata pelajaran Kimia }\end{array}$ & 1 & Guru & \\
\hline 30 & $\begin{array}{l}\text { Metode peningkatan kapasitas Guru } \\
\text { pemandu mata pelajaran Biologi }\end{array}$ & 1 & Guru & \\
\hline 31 & $\begin{array}{l}\text { Pemandu peningkatan kapasitas Guru } \\
\text { pemandu mata pelajaran Matematika }\end{array}$ & 1 & Guru & \\
\hline 32 & $\begin{array}{l}\text { Penataran pendidikan pendahuluan } \\
\text { bela negara }\end{array}$ & 1 & Staf & Komando Distrik Militer 0833 \\
\hline 33 & $\begin{array}{l}\text { Diklat internet bagi Guru SLTP Angkt. } \\
\text { IV }\end{array}$ & 1 & Guru & \multirow[t]{4}{*}{ Badan Diklat Prov.Jatim } \\
\hline 34 & Pelatihan teknik konseling Angkatan III & 1 & Pjb struktural & \\
\hline 35 & $\begin{array}{l}\text { Metode peningkatan kapasitas Guru } \\
\text { pemandu mata pelajaran IPS }\end{array}$ & 1 & Guru & \\
\hline & Jumlah & 488 & Orang & \\
\hline
\end{tabular}

Sumber data : Olahan data skunder pada BKD Kota Malang, 2018.

Tabel di atas memberikan informasi bahwa terdapat peningkatan jenis diklat teknis fungsional dari tahun ke tahun, yakni tahun 2018 sebanyak 35 jenis diklat teknis fungsional yang diikuti oleh 488 PNS. Sedangkan tahun 2019 berjumlah 43 jenis diklat teknis fungsional yang diikuti 130 Pegawai Negeri Sipil. Artinya dalam dua tahun terakhir Pemerintah Kota Malang telah meningkatkan keahlian aparaturnya sebanyak 518 orang, dengan keahlian 78 bidang tugas yang tersebar di bebagai unit kerja. Ini menandakan Pemerintah Kota Malang makin peduli pada peningkatan keahlian aparatur dalam lingkungannya. Di bawah ini diuraikan jenis diklat pada 2009.

Tabel 5.

Jumlah pegawai yang telah mengikuti diklat teknis fungsional Tahun 2017/2018

\begin{tabular}{|c|c|c|c|c|}
\hline No & Jenis Diklat & Jml & Status & Penyelenggara \\
\hline 1 & $\begin{array}{l}\text { Seminar reformasi pengawasan birokrasi } \\
\text { untuk meningkatkan kinerja }\end{array}$ & 1 & $\begin{array}{l}\text { Pjbt } \\
\text { struktural }\end{array}$ & $\begin{array}{llll}\text { Fakultas Ilmu Adm. Brawijaya } \\
\text { Malang }\end{array}$ \\
\hline 2 & $\begin{array}{l}\text { Pelatihan injeksi Bensin (EF-J Tronik, K-J } \\
\text { tronik }\end{array}$ & 1 & $\begin{array}{l}\text { Staf } \\
\text { bag.Umum }\end{array}$ & PPPPTK/VEDC \\
\hline 3 & Rakor penyelenggaraan diklatpim Tk.II & 1 & $\begin{array}{l}\text { Pjb } \\
\text { struktural }\end{array}$ & LAN \\
\hline 4 & Seminar pemerintahan & 3 & Camat & Pemerintah Prov. Jatim \\
\hline 5 & $\begin{array}{l}\begin{array}{l}\text { Sosialisasi \& konsultasi teknis diklat } \\
\text { aparatur }\end{array} \\
\end{array}$ & 1 & $\begin{array}{l}\text { Pjb } \\
\text { struktural }\end{array}$ & $\begin{array}{lll}\begin{array}{l}\text { Pusdiklat } \\
\text { Yogyakarta }\end{array} & \text { Depdagri } & \text { Regional } \\
\end{array}$ \\
\hline 6 & Rapat penentuan Index biaya diklat LPJ & 1 & $\begin{array}{l}\text { Pjb } \\
\text { struktural }\end{array}$ & Badan Diklat Prov. Jatim \\
\hline 7 & 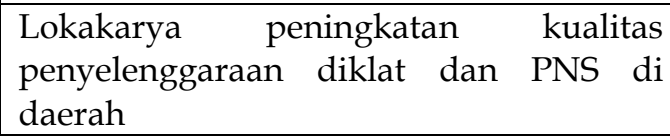 & 1 & $\begin{array}{l}\text { Pjb } \\
\text { struktural }\end{array}$ & PKP2A LAN \\
\hline
\end{tabular}




\begin{tabular}{|c|c|c|c|c|}
\hline No & Jenis Diklat & Jml & Status & Penyelenggara \\
\hline 8 & Analisis kebutuhan diklat & 1 & $\begin{array}{l}\text { Pjb } \\
\text { struktural }\end{array}$ & $\begin{array}{lll}\text { Pusdiklat } & \text { Depdari } & \text { Regional } \\
\text { Yogyakarta } & & \\
\end{array}$ \\
\hline 9 & $\begin{array}{l}\text { Management of training bagi pengelola } \\
\text { diklat }\end{array}$ & 1 & Staf & Badan Diklat prov. Jatim \\
\hline 10 & Manajemen pemerintahan kelurahan & 2 & $\begin{array}{l}\text { Pjb } \\
\text { struktural }\end{array}$ & Sda \\
\hline 11 & $\begin{array}{l}\text { Pengembangan ekonomi lokal dan usaha } \\
\text { daerah }\end{array}$ & 1 & Staf & Sda \\
\hline 12 & Manajemen organisasi & 2 & Staf & Sda \\
\hline 13 & Workshop Action Plan Diklat & 4 & $\begin{array}{ll}\text { PNS dan } \\
\text { Guru }\end{array}$ & Sda \\
\hline 14 & Pengarusutan gender bagi aparatur & 1 & Staf & Sda \\
\hline 15 & Orinetasi manajemen kediklatan & 1 & $\begin{array}{l}\mathrm{Pjb} \\
\text { struktural }\end{array}$ & Sda \\
\hline 16 & Metode dan teknik pembelajaran efektif & 1 & $\begin{array}{l}\mathrm{Pjb} \\
\text { struktural }\end{array}$ & PKP2A LAN \\
\hline 17 & Keprotokolan bagi staf bag. Keprotokolan & 1 & Staf & Badan Diklat Prov. Jatim \\
\hline 18 & $\begin{array}{l}\text { Pembekalan teknis kepala terminal } \\
\text { penumpang Angkatan ke VII }\end{array}$ & 2 & $\begin{array}{l}\text { Kpl. } \\
\text { terminal }\end{array}$ & Dirjen Perhubungan Darat \\
\hline 19 & $\begin{array}{l}\text { Poverty Alleviation Course : Localising } \\
\text { the Anti. Povery Agenda : The Malaysian } \\
\text { Experience }\end{array}$ & 1 & $\begin{array}{l}\text { Pjb } \\
\text { struktural }\end{array}$ & $\begin{array}{l}\text { Institute for Rural Advancement } \\
\text { (INFRA) }\end{array}$ \\
\hline 20 & Manajemen pemerintahan kelurahan & 28 & $\begin{array}{l}\text { Lurah dan } \\
\text { seklur }\end{array}$ & $\begin{array}{l}\text { Balai besar pemberdayaan } \\
\text { Masyarakat dan Desa }\end{array}$ \\
\hline 21 & Workoshop reformasi diklat Aparatur & 2 & $\begin{array}{l}\mathrm{Pjb} \\
\text { struktural }\end{array}$ & Badan Diklat Prov. Jatim \\
\hline 22 & $\begin{array}{l}\text { Penyuluhan penguatan kapasitas } \\
\text { pembangunan kelurahan }\end{array}$ & 19 & $\begin{array}{l}\text { Pjb } \\
\text { struktural }\end{array}$ & $\begin{array}{lll}\begin{array}{l}\text { Lembaga } \\
\text { pengabdian }\end{array} & \text { penelitian } & \text { dan } \\
\end{array}$ \\
\hline 23 & Diklat Manajemen persampahan & 1 & Staf & Badan Diklat Prov. Jatim \\
\hline 24 & $\begin{array}{l}\text { Diklat Tata Ruang dan Manajemen lahan } \\
\text { perkotaam }\end{array}$ & 1 & Staf & Sda \\
\hline 25 & Diklat manajemen partisipatif masyarakat & 1 & Staf & Sda \\
\hline 26 & Bintek layanan TAPERUM-PNS & 1 & $\begin{array}{l}\text { Pjb } \\
\text { struktural }\end{array}$ & BAPERTARUM PNS \\
\hline 27 & $\begin{array}{l}\text { Monitoring dan evaluasi program proyek } \\
\text { pembangunan }\end{array}$ & 20 & $\begin{array}{l}\text { Pjb } \\
\text { struktural }\end{array}$ & $\begin{array}{llll}\text { RCCP fakultas } & \text { Ilmu } & \text { Adm. } \\
\text { UNIBRAW } & & \\
\end{array}$ \\
\hline 28 & $\begin{array}{l}\text { Seminar Nasional penyusunan pedoman } \\
\text { umum monev pengadaan barang/jasa } \\
\text { pemeintah }\end{array}$ & 1 & $\begin{array}{l}\text { Pjb } \\
\text { struktural }\end{array}$ & $\begin{array}{l}\text { Lembaga kebijakan pengadaan } \\
\text { barang/jasa pemerintah }\end{array}$ \\
\hline 29 & $\begin{array}{l}\text { Workshop trainning of trainer managers } \\
\text { Angkatan III }\end{array}$ & 1 & $\begin{array}{l}\mathrm{Pjb} \\
\text { struktural }\end{array}$ & SCBD LAN \\
\hline 30 & Rapat koordinasi teknis kehumasan & 1 & $\begin{array}{l}\text { Opjb } \\
\text { struktural }\end{array}$ & Biro humas dan Protokol Jatim \\
\hline 31 & $\begin{array}{l}\text { Bimbingan teknis Akuntansi Keuangan } \\
\text { Daerah }\end{array}$ & 10 & Staf & $\begin{array}{l}\text { Dirjen perimbangan keuangan \& } \\
\text { kapasitas daerah }\end{array}$ \\
\hline 32 & $\begin{array}{l}\text { Transformasi kebijakan pemerintahan } \\
\text { daerah }\end{array}$ & 1 & Camat & Badan Diklat Prov. Jatim \\
\hline 33 & Kursus keuangan daerah & 1 & $\begin{array}{l}\text { Pjb } \\
\text { struktural }\end{array}$ & UNIBRAW \\
\hline 34 & Pembinaan wilayah Angkatan II & 1 & Camat & Pemerintah Prov. Jatim \\
\hline 45 & Diklat English For Tourism & 1 & $\begin{array}{l}\text { Pjb } \\
\text { struktural }\end{array}$ & Badan Diklat Jatim \\
\hline
\end{tabular}




\begin{tabular}{|c|l|l|l|l|}
\hline No & \multicolumn{1}{|c|}{ Jenis Diklat } & Jml & \multicolumn{1}{|c|}{ Status } & \multicolumn{1}{|c|}{ Penyelenggara } \\
\hline 36 & $\begin{array}{l}\text { Pembekalan peningkatan pemahaman } \\
\text { sistem deteksi dini dan cegah dini } \\
\text { terhadap konflik di masyarakat bagi } \\
\text { aparatur pemda }\end{array}$ & 2 & Camat & Pemrov. Jawa Timur \\
\hline 37 & Peningkatan kapasitas seklur angkatan I & 2 & Seklur & Badan diklat Prov. Jatim \\
\hline 38 & Pengembangan kawasan Agropolitan I & 1 & Penyuluh & Sda \\
\hline 39 & $\begin{array}{l}\text { Workshop perumusan instrumen evaluasi } \\
\text { diklat }\end{array}$ & 1 & $\begin{array}{l}\text { Pjbt } \\
\text { struktural }\end{array}$ & Sda \\
\hline 40 & Workshop reformasi kediklatan & 2 & $\begin{array}{l}\text { Pejb dan } \\
\text { staf }\end{array}$ & Sda \\
\hline 41 & Evaluasi dampak diklat & 1 & Camat & Sda \\
\hline 42 & $\begin{array}{l}\text { Sosialisasi pedoman akreditasi Lembaga } \\
\text { Kediklatan Pemerintah }\end{array}$ & 1 & Staf & Sda \\
\hline 43 & Diklat angkutam umum & 1 & Staf & Sda \\
\hline & Jumlah & 130 & Orang & \\
\hline
\end{tabular}

Sumber : Olahan data skunder pada BKD Kota Malang, 2018.

Rincian data di atas menggambarkan jenis diklat teknis fungsional yang telah dilaksanakan selama dua tahun yaitu 2018 dan 2019. Jenis diklat teknis fungsional yang sudah dilaksanakan tersebut bukan berarti pada tahun-tahun berikutnya tidak diadakan lagi, tetapi substansi diklat dimaksud masih sangat diperlukan, karena jenis diklat tersebut menjadi erat kaitannya dengan tugas organisasi, sehingga setiap orang harus mengikutinya dalam rangka regenerasi penguasaan di bidang tugasnya masing-masing.

Dalam rangka peningkatan kapasitas aparatur pemerintah, Pemerintah Kota Malang mendapatkan proyek Sustainable Capacity Building for Decentralition (SCBD). Dasar pemikiran SCBD-P mengacu pada kebutuhan dalam rangka penyesuaian kebijakan-kebijakan dan peraturanperaturan reformasi kelembagaan, modifikasi prosedur-prosedur kerja dan mekanisme-mekanisme koordinasi, peningkatan keterampilan dan kualifikasi sumber daya manusia, perubahan sikap dan nilai dan sikap atau perilaku, sehingga dapat menunjang kebutuhan otonomi daerah ke arah pemerintahan yang baik (good governance). Perbaikan peningkatan kapasitas diharapkan dapat meningkatkan kapasitas operasional pemerintah daerah berkenaan dengan efisiensi penyediaan jasa pelayanan berdasarkan standar pelayanan minimal, promosi pembangunan ekonomi yang berkeadilan, dan manajemen penanggulangan kemiskinan, dan juga untuk menuju tata pemerintahan yang baik. Oleh karena itu, perlu upaya yang terkoordinir dalam menjamin agar tujuantujuan dan sasaran-sasaran kebijakan otonomi daerah dapat tercapai.

Keberhasilan pelaksanaan berbagai kegiatan tersebut ditentukan oleh sumber daya manusia, sehingga dasar pendekatan SCBD adalah penerapan konsep pembangunan yang berkelanjutan (sustainable development) didukung dengan pendekatan pembangunan manusia, sebagai manifestasi paradigma pembangunan manusia. Pendekatan ini dimaksudkan adalah untuk terjadinya perubahan sikap dan karakter aparatur pemerintah yaitu mengembangkan kepekaan, bertanggung jawab, baik objective responsibility maupun subjective responsibility dan representatif (representativeness), yaitu tidak menyalahgunakan wewenang (power abuse) maupun melampaui wewenang yang dimiliki (excessive power) dalam pelaksanaan tugas, dan penerapan sistem desentralisasi 
secara proporsional yang berarti kemampuan pemerintah daerah mengembangkan potensi daerah untuk kepentingan publik. Sehingga proyek ini memiliki lima indikator peningkatan kapasitas, yaitu peningkatan pelayanan kepada masyarakat, peningkatan ekonomi daerah, penurunan angka kemiskinan, percepatan desentralisasi, dan terciptanya good governance.
Proyek SCBD Kota Malang mulai dilaksanakan pada bulan September 2009 yang diawali dengan Launching Proyek Sustainable Capacity Building for Decentralization (SCBD).

Diklat peningkatan kapasitas berkelanjutan (SCBD) di Kota Malang berjumlah 47 jenis pendidikan dan pelatihan sebagai berikut :

Tabel 6.

Jenis diklat Sustainable Capacity Building Decentralization (SCBD)

\begin{tabular}{|c|c|c|c|}
\hline No & Jenis Diklat & No & Jenis Diklat \\
\hline 1 & Perencanaan dan pembangunan daerah & 24 & \begin{tabular}{|lll}
$\begin{array}{l}\text { Penyusunan } \\
\text { gender }\end{array}$ & kebijakan & pengarusutaman \\
\end{tabular} \\
\hline 2 & Pelayanan publik dan Akuntabilitas & 25 & Survei kepusaan pelanggan (CSS) masyarakat \\
\hline 3 & Manajemen Asset. & 26 & Survei kepuasaan pelanggan dunia usaha \\
\hline 4 & $\begin{array}{l}\text { Kesetaraan Gender dan Pengarusataman } \\
\text { Gender }\end{array}$ & 27 & $\begin{array}{lll}\begin{array}{l}\text { Penyempurnaan penetapan kewenangan } \\
\text { daerah }\end{array} & \\
\end{array}$ \\
\hline 5 & Pengentasan kemiskinan & 28 & $\begin{array}{l}\text { Penyempurnaan peraturan perundang-undang } \\
\text { bidang lingkungan hidup }\end{array}$ \\
\hline 6 & Analisa Potensi peningkatan pendapatan & 29 & \begin{tabular}{|ll}
$\begin{array}{l}\text { Pengadaan software sistem informasi } \\
\text { manajemen kependudukan }\end{array}$ & \\
\end{tabular} \\
\hline 7 & Administrasi umum & 30 & Pengadaan sistem manajemen aset \\
\hline 8 & lan pengembangan SDM & 31 & $\begin{array}{l}\text { Pengadaan sistem informasi manajemen } \\
\text { perencanaan pembangunan }\end{array}$ \\
\hline 9 & $\mathrm{~K}$ & 32 & Pengadaan software sistem investasi \\
\hline 10 & ra & 33 & gan sistem perencanaan $\mathrm{p}$ \\
\hline 11 & proyek & 34 & \begin{tabular}{|lll}
$\begin{array}{l}\text { Pengembambangan } \\
\text { penempatan pegawai }\end{array}$ & sistem & seleksi
\end{tabular} \\
\hline 12 & Analisa potensi daerah & 35 & \begin{tabular}{|lrrr}
$\begin{array}{l}\text { Pengembang. sistem penilaian individu } \\
\text { pegawai }\end{array}$ & & \\
\end{tabular} \\
\hline 13 & in & 36 & Pengembangan sistem perencanaan karier \\
\hline 14 & Puk & 37 & diklat \\
\hline 15 & Orientasi gender & 38 & Perencanaan \& manajem.ekonomi daerah \\
\hline 16 & \begin{tabular}{|lrl} 
Komputerisasi & sistem & administrasi \\
kecamatan dan kelurahan
\end{tabular} & 39 & \begin{tabular}{|lcc}
$\begin{array}{l}\text { Penyusunan } \\
\text { infortmasi }\end{array}$ & dan pengembangan sistem \\
pembangunan
\end{tabular} \\
\hline 17 & $\begin{array}{l}\text { Kursus penyusunan ketentuan-ketentuan } \\
\text { hukum }\end{array}$ & 40 & Orientasi gender dan permasalahannya \\
\hline 18 & Pengadaan barang dan jasa. & 41 & $\begin{array}{l}\text { Studi penggalian potensi sumber pembiayaan } \\
\text { program peningkatan kapasitas berkelanjutan }\end{array}$ \\
\hline 19 & Teknis desain sistem informasi manaj & 42 & Survei audit kinerja pemerintah daerah \\
\hline 20 & $\begin{array}{l}\text { Penyusunan kerangka kebijakan } \\
\text { penyelenggaraan good and clean governance }\end{array}$ & 43 & $\begin{array}{l}\text { Penyusunan sistem pemantauan dan } \\
\text { pengukuran kegiatan peningkatan kapasitas } \\
\text { pemerintahan daerah }\end{array}$ \\
\hline 21 & $\begin{array}{l}\text { Penyusunan dan penyempurnaan standar } \\
\text { pelayanan minimal (SPM) }\end{array}$ & 44 & \begin{tabular}{|l}
$\begin{array}{l}\text { Penyusunan sistem evaluasi peningkatan } \\
\text { kapasitas }\end{array}$ \\
\end{tabular} \\
\hline 22 & $\begin{array}{l}\text { Pengkajian \& penyempurnaan prosedur } \\
\text { tetap pelayanan pemerintahan daerah }\end{array}$ & 45 & Penyusunan sistem pendukung AKIP/LAKIP \\
\hline 23 & & 46 & Analisis jabatan dan pengukuran beban kinerja \\
\hline
\end{tabular}




\begin{tabular}{|c|c|c|c|}
\hline No & \multicolumn{1}{|c|}{ Jenis Diklat } & No & Jenis Diklat \\
\hline & $\begin{array}{l}\text { Penyusunan kerangka dan strategi kebijakan } \\
\text { penanggulangan kemiskinan berpresfektif } \\
\text { gender }\end{array}$ & 47 & Pelatihan administrasi umum \\
\hline
\end{tabular}

Sumber data : Dokumen Bappeda Kota Malang

Sampai dengan akhir Februari 2010 sudah beberapa materi pelatihan yang telah dilaksanan antara lain, pelatihan manajemen proyek, pelatihan gender, pelatihan komputer, penyusunan rencana strategis, pelatihan public service, pelatihan manajemen dan pengembangan SDM, pelayanan publik dan akuntabilitas, pelatihan analisis potensi daerah, pelatihan manajemen aset, dan lain-lain. Setiap awal dan akhir diklat diadakan evaluasi. Tes ini bukan menentukan apakah pegawai diterima atau tidak untuk menjadi peserta diklat, atau tidak bermaksud lulus atau tidaknya seseorang, melainkan lebih untuk mengetahui sejauhmana perbandingan perubahan antara sebelum dan sesudah mengikuti diklat.

Hasil survei audit kinerja oleh tim proyek SCBD Kota Malang yang dilokakaryakan pada tanggal 1 Maret 2010 di Hotel Wisata Tidar Malang, bahwa pada umumnya kinerja Pemerintah Kota Malang sudah baik, dan sebagian besar pelanggan (masyarakat dan dunia usaha) menyatakan puas atas kinerja Pemerintah Kota Malang tersebut, namun juga masih ada yang perlu ditingkatkan. Untuk mengetahui hasil audit dimaksud dapat dilihat pada rincian tabel berikut ini :

\section{Tabel 7.}

Survei Audit Kinerja Pemerintah Kota Malang, Kepuasan Pelanggan (Masyarakat), dan Kepuasan (Pelanggan) Dunia Usaha di Kota Malang

\begin{tabular}{|c|c|c|}
\hline $\begin{array}{c}\text { Aspek kinerja } \\
\text { yang disurvei } \\
\text { (bidang) }\end{array}$ & $\begin{array}{l}\text { Indikator bidang } \\
\text { audit }\end{array}$ & Hasil Audit Kinerja Pemerintah Kota Malang \\
\hline \multicolumn{3}{|c|}{ Kinerja Pemerintah Kota Malang } \\
\hline \multirow[t]{5}{*}{$\begin{array}{l}\text { a. Administrasi } \\
\text { Umum }\end{array}$} & $\begin{array}{l}\text { Restrukturisasi } \\
\text { Pemerintah Kota } \\
\text { Malang }\end{array}$ & $\begin{array}{l}\text { Restrukturisasi telah dilakukan dan disesuaikan dengan peraturan } \\
\text { terbaru serta didasarkan atas kebutuhan TUPOKSI }\end{array}$ \\
\hline & $\begin{array}{ll}\text { Training } & \text { Need } \\
\text { Assesment }\end{array}$ & $\begin{array}{l}\text { Sebagian besar SKPD telah melakukan yang diikuti pula dengan } \\
\text { pelaksanaan pelatihan untuk memenuhi kebutuhan TOPOKSI, } \\
\text { namun belum terlaksana seluruhnya, sehingga tingkat } \\
\text { pelaksanaan pelatihan yang sesuai dengan kebutuhan hanya } \\
\text { mencapai } 75 \% \text {. }\end{array}$ \\
\hline & $\begin{array}{l}\text { Waktu } \\
\text { penanganan tugas }\end{array}$ & $\begin{array}{l}\text { Sebagian besar SKPD telah mengembangkan target waktu dan } \\
\text { mengimplementasikan untuk menangani tugas-tugas sehari-hari, } \\
\text { dan dalam proses pelaksanaan telah dilakukan indentifikasi dalam } \\
\text { rangka meminimalisir kesempatan terjadinya korupsi dan } \\
\text { sekaligus memiliki program pendidikan terstruktur. }\end{array}$ \\
\hline & $\begin{array}{l}\text { Prosedur } \\
\text { operasional } \\
\text { standar }\end{array}$ & $\begin{array}{l}\text { Mayoritas responden menyatakan SOP tentang pemberian hadiah } \\
\text { kepada pegawai oleh supplier, para kontraktor telah ada. }\end{array}$ \\
\hline & $\begin{array}{l}\text { Tanggapan } \\
\text { terhadap } \\
\text { laporan/ keluhan }\end{array}$ & $\begin{array}{l}\text { Sebagian kasus ditindaklanjuti sampai ke penuntut umum, } \\
\text { sedangkan sebagian lainnya ditindaklanjuti secara internal. }\end{array}$ \\
\hline
\end{tabular}




\begin{tabular}{|c|c|c|}
\hline \multirow[t]{5}{*}{$\begin{array}{l}\text { Aspek kinerja } \\
\text { yang disurvei } \\
\text { (bidang) }\end{array}$} & $\begin{array}{l}\text { Indikator bidang } \\
\text { audit }\end{array}$ & Hasil Audit Kinerja Pemerintah Kota Malang \\
\hline & $\begin{array}{l}\text { tentang korupsi, } \\
\text { vervariasi }\end{array}$ & \\
\hline & $\begin{array}{l}\text { Transparansi } \\
\text { biaya perijinan } \\
\text { adm. dasar }\end{array}$ & $\begin{array}{l}\text { Transparansi terhadap biaya pelayanan perijinan administrasi } \\
\text { dasar (register dan permohonan izin) telah dilakukan melalui } \\
\text { pamflet/leaflet di masing-masing kantor yang terkait dengan } \\
\text { pelayanan tersebut. }\end{array}$ \\
\hline & Standar kerja & $\begin{array}{l}\text { Secara umum standar kerja di sebagian besar komponen } \\
\text { Pemerintah Kota Malang telah diimplementasikan khususnya } \\
\text { menyangkut batas waktu untuk menangani kertas kerja, sementara } \\
\text { sebagian komponen pemkot masih dalam proses untuk } \\
\text { mengimplementasikan standar dimaksud. }\end{array}$ \\
\hline & Sistem kerja & $\begin{array}{l}\text { Sebagian besar Pemkot Malang telah memiliki sistem yang } \\
\text { komprehensif untuk mengatur peralatan yang berlebihan atau } \\
\text { sudah tidak dapat digunakan. }\end{array}$ \\
\hline \multirow[t]{6}{*}{$\begin{array}{l}\text { b. Manajemen } \\
\text { Keuangan }\end{array}$} & $\begin{array}{l}\text { Pengelolaan } \\
\text { keuangan daerah } \\
\text { secara transparan }\end{array}$ & $\begin{array}{l}\text { Secara umum pengelolaan keuangan daerah telah mengikuti } \\
\text { pedoman yang berlaku secara nasional. Namun demikian dalam } \\
\text { beberapa aspek belum sepenuhnya diimplementasikan. }\end{array}$ \\
\hline & $\begin{array}{l}\text { Penyusunan } \\
\text { APBD }\end{array}$ & $\begin{array}{l}\text { Perencanaan keuangan daerah telah mengikuti proses sesuai } \\
\text { ketentuan yang berlaku. Di samping itu, secara formal telah } \\
\text { menerapkan anggaran berbasis kinerja pada tataran kebijakan, } \\
\text { serta telah memperhatikan urusan-urusan wajib sebagai prioritas } \\
\text { dalam alokasi APBD pada sebagian besar komponen. }\end{array}$ \\
\hline & Penyusunan PAD & $\begin{array}{l}\text { Pemerintah Kota Malang telah melakukan analisis potensi } \\
\text { sehingga penentuan rencana jumlah pendapatan mendekati } \\
\text { potensi riil, dan seluruh penerimaan telah diperbandingkan } \\
\text { dengan tingkat inflasi. }\end{array}$ \\
\hline & $\begin{array}{l}\text { Pengeluaran atau } \\
\text { belanja }\end{array}$ & $\begin{array}{l}\text { Pada sisi pengeluaran atau belanja di samping pengalokasiannya } \\
\text { diprioritaskan untuk melaksanakan kewenangan wajib dan } \\
\text { pilihan, informasi status penyerapan anggaran dapat diakses oleh } \\
\text { sebagian besar komponen pemerintah Kota Malang sehingga } \\
\text { efisiensi penggunaan anggaran dan pelaksanaan program dan } \\
\text { kegiatan yang telah direncanakan dapat berjalan dengan baik. }\end{array}$ \\
\hline & $\begin{array}{l}\text { Penggunaan } \\
\text { Sistem } \\
\text { komputerisasi } \\
\text { dalam akuntansi } \\
\text { keuangan }\end{array}$ & $\begin{array}{l}\text { Pemerintah Kota Malang telah menggunakan komputerisasi dan } \\
\text { telah diinstan sesuai peraturan yang berlaku, termasuk penerapan } \\
\text { sistem pembukuan dan penerapan berbasis kas modifikasi. }\end{array}$ \\
\hline & $\begin{array}{l}\text { Transparansi } \\
\text { keuangan }\end{array}$ & $\begin{array}{l}\text { Transparansi keuangan belum dilaksanakan secara optimal, } \\
\text { Pemerintah Kota Malang belum mempublikasikan laporan } \\
\text { keuangan secara terbuka melalui internet.media massa. Namun } \\
\text { direncanakan akan dilaksanakan tahun depan. }\end{array}$ \\
\hline \multirow[t]{2}{*}{ c. Bidang Audit } & $\begin{array}{l}\text { Pengawasan } \\
\text { terhadap } \\
\text { keuangan }\end{array}$ & $\begin{array}{l}\text { Telah dibentuk pengawasan internal, auditor mempunyai jabatan } \\
\text { atau posisi fungsional. Sebagian besar staf staf auditor telah dilatih } \\
\text { untuk meningkatkan pengetahuan dan keterampilan, namun } \\
\text { sampai saat ini Pemerintah Kota Malang belum mengikutkan } \\
\text { auditor independen dalam pengawasan keuangan. }\end{array}$ \\
\hline & $\begin{array}{l}\text { Program tahunan } \\
\text { audit internal }\end{array}$ & $\begin{array}{l}\text { Program tahunan audit internal inspektorat sebagian besar telah } \\
\text { diimplementasikan dan hasil temuan auditor sebagian besar } \\
\text { ditindaklanjuti keputusan Walikota sampai dimonitor oleh pihak } \\
\text { DPRD melalui debat di DPRD dan belum sampai pada } \\
\text { pembentukan komite khusus. }\end{array}$ \\
\hline
\end{tabular}




\begin{tabular}{|c|c|c|}
\hline $\begin{array}{l}\text { Aspek kinerja } \\
\text { yang disurvei } \\
\text { (bidang) }\end{array}$ & $\begin{array}{l}\text { Indikator bidang } \\
\text { audit }\end{array}$ & Hasil Audit Kinerja Pemerintah Kota Malang \\
\hline & $\begin{array}{l}\text { Respon terhadap } \\
\text { keluhan } \\
\text { masyarakat }\end{array}$ & $\begin{array}{l}\text { Auditor juga juga merespon sebagian keluhan masyarakat tentang } \\
\text { penyelidikan penyimpangan alokasi keuangan baik melalui } \\
\text { pencatatan secara sistematis maupun penanganan keluhan } \\
\text { tersebut dengan menetapkan target waktu tertentu. }\end{array}$ \\
\hline \multirow[t]{5}{*}{$\begin{array}{l}\text { d.Pengembang } \\
\text { an organisasi } \\
\text { dan SDM }\end{array}$} & $\begin{array}{l}\text { Objektivitas } \\
\text { kriteria } \\
\text { penerimaan } \\
\text { CPNS }\end{array}$ & $\begin{array}{l}\text { Mayoritas responden menyatakan bahwa objektivitas kriteria yang } \\
\text { digunakan dalam penerimaan PNS telah mengikuti prosedur. }\end{array}$ \\
\hline & $\begin{array}{l}\text { Objektivitas } \\
\text { kriteria promosi } \\
\text { struktural }\end{array}$ & $\begin{array}{l}\text { Mayoritas menilai bahwa kriteria yang digunkana dalam proses } \\
\text { pegawai untuk dipromosi jabatan struktural dilakukan proses } \\
\text { seleksi jabatan pegawai yakni } 83 \% \text {. Hasil uraian tugas dan } \\
\text { tanggung jawab digunakan sebagai kriteria dalam menentukan } \\
\text { seseorang dapat dipromosikan. }\end{array}$ \\
\hline & $\begin{array}{l}\text { Sistem evaluasi } \\
\text { kinerja tahunan }\end{array}$ & $\begin{array}{l}85 \% \text { menyatakan kinerja telah dilakukan evaluasi tahunan untuk } \\
\text { semua staf, namun masih ada juga yang belum dilakukan. }\end{array}$ \\
\hline & $\begin{array}{l}\text { Sistem evaluasi } \\
\text { DP3 }\end{array}$ & $\begin{array}{l}\text { Sistem evaluasi untuk memperbaiki DP3 telah disosialisasikan, } \\
\text { tetapi masih relatif banyak yang belum tahu. }\end{array}$ \\
\hline & $\begin{array}{l}\text { Peningkatan } \\
\text { pengetahuan }\end{array}$ & $\begin{array}{l}\text { Proposisi pegawai fungsional dan struktural secara mayoritas } \\
\text { menyatakan telah memiliki peningkatan keahlian dan peningkatan } \\
\text { kompetensi melalui pelatihan keahlian, dan juga staf. }\end{array}$ \\
\hline \multirow[t]{2}{*}{$\begin{array}{l}\text { e. Informasi dan } \\
\text { komunikasi }\end{array}$} & Jaringan internet & $\begin{array}{l}\text { Seluruh komponen yang ada pada pemerintah daerah Kota } \\
\text { Malang telah dilengkapi jaringan internet yang terhubung dengan } \\
\text { kantor Walikota dan kantor Sekda, namun sebagian SKPD belum } \\
\text { mengetahui keberadaan internet sehingga belum dimanfaatkan } \\
\text { secara optimal. }\end{array}$ \\
\hline & $\begin{array}{l}\text { Berbasis data dan } \\
\text { status kerja dan } \\
\text { pemanfaatannya }\end{array}$ & $\begin{array}{l}\text { Sebagian komponen pemkot telah tersedia, namun pemanfaatan } \\
\text { basis data belum berjalan secara optimal karena sebagian data dari } \\
\text { beberapa komponen pemkot belum tersedia dan beberapa jenis } \\
\text { data masih sulit untuk diakses. }\end{array}$ \\
\hline $\begin{array}{l}\text { f. Perencanaan } \\
\text { pembangunan }\end{array}$ & $\begin{array}{l}\text { Keterlibatan } \\
\text { stakeholder dlm } \\
\text { perencanaan }\end{array}$ & $\begin{array}{l}\text { Keterlibatan stakeholder dalam perencanaan pembangunan Kota } \\
\text { Malang sudah berjalan dengan baik. }\end{array}$ \\
\hline $\begin{array}{l}\text { g. pengadaan } \\
\text { barang dan } \\
\text { jasa }\end{array}$ & $\begin{array}{l}\text { Prosedur dan } \\
\text { pelaksanaannya }\end{array}$ & $\begin{array}{l}\text { Dalam menerapkan prosedur pengadaan barang dan jasa yang } \\
\text { transparan dan bersih, DPRD sudah menggunakan Keppres } \\
\text { 80/2003, Metode sistem skoring juga digunakan untuk menyeleksi } \\
\text { tender dengan sistem publikasi. Pelaksanaan tender dibuka secara } \\
\text { umum di media disesuaikan dengan besar nilai pagu. Untuk nilai } \\
\text { pagu menengah dan besar dilakukan dengan media regional dan } \\
\text { nasional, sedangkan nilai pagu rendah cukup dengan media lokal. }\end{array}$ \\
\hline \multicolumn{3}{|c|}{ Kepuasan Pelanggan (Masyarakat) } \\
\hline \multirow{2}{*}{$\begin{array}{l}\text { Pelayanan } \\
\text { Administrasi } \\
\text { Umum }\end{array}$} & $\begin{array}{l}\text { Kualitas } \\
\text { pelayanan }\end{array}$ & $\begin{array}{l}\text { Secara umum kualitas pelayanan yang diberikan SKPD yang } \\
\text { terkait dengan pelayanan dasar memuaskan. }\end{array}$ \\
\hline & $\begin{array}{l}\text { Penilaian } \\
\text { masyarakat }\end{array}$ & $\begin{array}{l}\text { Penilaian masyarakat terhadap kualitas layanan administrasi dasar } \\
\text { yang terbaik, yalni pendaftaran kelahiran atau kematian anggota } \\
\text { keluarga, pengurusan KTP, IMB, hak tanah, dan layanan jasa pada } \\
\text { saat mengurus lisensi bisnis atau perijinan lainnya adalah puas. }\end{array}$ \\
\hline $\begin{array}{l}\text { Infrastruktu } \\
\text { publik dan } \\
\text { lingkungan }\end{array}$ & $\begin{array}{l}\text { Keberadaan } \\
\text { infrastruktur } \\
\text { publik }\end{array}$ & $\begin{array}{l}\text { Secara umum keberadaan infrastruktur publik dan lingkungan, } \\
\text { meliputi kualitas jalan, drainase, dan kebersihan, penerangan, } \\
\text { serta ketersediaan trotoar adalah baik. }\end{array}$ \\
\hline
\end{tabular}




\begin{tabular}{|c|c|c|}
\hline $\begin{array}{l}\text { Aspek kinerja } \\
\text { yang disurvei } \\
\text { (bidang) }\end{array}$ & $\begin{array}{l}\text { Indikator bidang } \\
\text { audit }\end{array}$ & Hasil Audit Kinerja Pemerintah Kota Malang \\
\hline & $\begin{array}{l}\text { Kualitas } \\
\text { kebersihan di } \\
\text { lingkungan } \\
\text { tempat tinggal }\end{array}$ & $\begin{array}{l}\text { Kualitas kebersihan di lingkungan tempat tinggal, penerangan } \\
\text { jalan, jalang lingkungan, dan draainase serta penyediaan trotoar } \\
\text { adalah baik. }\end{array}$ \\
\hline & $\begin{array}{l}\text { Tanggapan } \\
\text { masyarakat atas } \\
\text { ketersediaan } \\
\text { PDAM, MCK }\end{array}$ & $\begin{array}{l}\text { Masyarakat menilai ketersediaan PDAM, jasa pembuangan limbah } \\
\text { dan jasa MCK secara umum memadai dan masyarakat puas. }\end{array}$ \\
\hline $\begin{array}{l}\text { Transportasi } \\
\text { publik dan } \\
\text { manajemen lalu } \\
\text { lintas }\end{array}$ & $\begin{array}{l}\text { Jasa transportasi } \\
\text { umum dan } \\
\text { pengaturan lalu } \\
\text { lintas }\end{array}$ & $\begin{array}{l}\text { Penilaian masyarakat terhadap jasa transportasi umum dan } \\
\text { pengaturan lalulintas secara umum memadai, sementara } \\
\text { masyarakat merasa puas atas manajemen lalulintas. }\end{array}$ \\
\hline $\begin{array}{l}\text { Jasa layanan } \\
\text { penampung } \\
\text { sampah, } \\
\text { pencegah dan } \\
\text { pemadaman } \\
\text { kebakaran }\end{array}$ & Layanan jasa & $\begin{array}{l}\text { Masyarakat menilai jasa penampungan sampah, pencegahan serta } \\
\text { pemadaman kebakaran secara umum dinilai memadai, sehinga } \\
\text { masyarakat merasa puas. }\end{array}$ \\
\hline \multirow[t]{2}{*}{$\begin{array}{l}\text { Pelayanan } \\
\text { pelayanan dasar }\end{array}$} & $\begin{array}{l}\text { Fasilitas } \\
\text { pendidikan,keseh } \\
\text { atan dan olah } \\
\text { raga }\end{array}$ & $\begin{array}{l}\text { Untuk fasilitas pendidikan sebagian besar mesyarakat masih } \\
\text { memanfaatkan fasilitas sekolah negeri, fasilitas kesehatan } \\
\text { pemanfaatan jasa yang diberikan pemda dan swasta berimbang }\end{array}$ \\
\hline & $\begin{array}{l}\text { Pemanfaatan } \\
\text { fasilitas }\end{array}$ & $\begin{array}{l}\text { Bahwa masyarakat menyatakan puas memanfaatkan fasilitas } \\
\text { pelayanan sosial dasar yang disediakan pemerintah. }\end{array}$ \\
\hline \multicolumn{3}{|c|}{ Kepuasan Masyarakat Dunia Usaha } \\
\hline \multicolumn{2}{|c|}{$\begin{array}{l}\text { Pelayanan adm.dasar yang diberikan } \\
\text { pemerintah }\end{array}$} & $\begin{array}{l}\text { Pelayanan adm.dasar meliputi pengurusan IMB, Ijin Usaha, Ijin } \\
\text { lingkungan, dan pembayaran pajak, kepuasan masyarakat dunia } \\
\text { usaha pada umumnya merasa puas. }\end{array}$ \\
\hline \multicolumn{2}{|c|}{$\begin{array}{l}\text { Respon terhadap penyediaan } \\
\text { infrastruktur dan fasilitas umum }\end{array}$} & $\begin{array}{l}\text { Berdasarkan prosentase hasil survei bahwa penyediaan } \\
\text { infrastruktur dan fasilitas umum adalah baik, tetapi masih perlu } \\
\text { perbaikan. }\end{array}$ \\
\hline \multicolumn{2}{|c|}{$\begin{array}{l}\text { Upaya-upaya Pemerintah Kota } \\
\text { Malang dalam rangka menunjang } \\
\text { pengembangan kegiatan usaha }\end{array}$} & $\begin{array}{l}\text { Terhadap upaya-upaya yang dilakukan dalam rangka menunjang } \\
\text { pengembangan kegiatan usaha di Kota Malang sudah dilakukan, } \\
\text { dan masyarakat dunia usaha merasa puas atas upaya-upaya } \\
\text { tersebut. }\end{array}$ \\
\hline
\end{tabular}

Sumber : Dokumen Hasil survei audit tim SCBD Kota Malang.

Hasil survei di atas menggambarkan kinerja organisasi Pemerintah Kota Malang pada umumnya sudah mendapat apresiasi dari masyarakat. Ini menunjukkan bahwa diklat SCBD mempunyai dampak positif bagi peningkatan kinerja, walaupun masih ada beberapa komponen belum baik. Salah satu yang mempengaruhi belum optimalnya kinerja dari beberapa indikator survei tersebut adalah kurang memanfaatkan keahlian atau keterampilan aparatur pemerintah yang telah diperoleh dari pendidikan dan pelatihan.

\section{PENUTUP}

Desentralisasi

pemerintahan merupakan sarana untuk mewujudkan pemerintahan yang baik (good governance). Implikasi dari penyelenggaraan pemerintahan yang baik dapat meningkatkan pelayanan publik yang berkualitas. Tujuan tersebut dapat dicapai bila didukung oleh sumber daya aparatur 
yang berkualitas. Untuk mewujudkan aparatur tersebut dibutuhkan strategi pengembangan yang kontiniu dan terprogram. Salah satunya dengan menerapkan organisasi pembelajar (learning organization) secara efektif.

Membangun organisasi pembelajar dalam rangka pengembangan sumberdaya aparatur dalam institusi pemerintahan bukan hanya penting melainkan sangat dibutuhkan. Aplikasi organisasi pembelajar tersebut dilakukan melalui lima disiplin sebagai jalur transformasi atau pengembangan kapasitas aparatur pemerintah. Hasil dari aplikasi organisasi pembelajar ini dapat memperbaiki pengetahuan, kemampuan, mindset dan model mental aparatur pemerintah, sehingga dapat mengatikulasikan nilai-nilai administrasi publik yakni pelayanan publik dengan baik.

Kesimpulan penelitian bahwa organisasi pembelajar dalam rangka pengembangan aparatur pada Pemerintah Kota Malang telah diaplikasikan akan tetapi belum optimal, sehingga organisasi belum sepenuhnya mampu merubah struktur berbasis tim, memperbesar kompetensi dan model mental aparatur, serta membangun budaya transfer pengetahuan. Implikasinya adalah organisasi tidak segera mencapai kinerja yang maksimal. Hal ini disebabkan masih terdapatnya beberapa kelemahan. Secara khusus kelemahan-kelemahan tersebut terkait dengan lima disiplin organisasi pembelajar yang diuraikan sebagai berikut :

Pertama, keahlian pribadi aparatur pada pemerintah Kota Malang masih rendah, dilihat dari rendahnya kemauan dan kemampuan di dalam mengembangkan diri secara terus menerus meskipun aparatur bersangkutan menyadari masih terdapat keterbatasan kemampuan dan keterampilannya. Di samping itu, masih terdapatnya aparatur yang belum diberdayakan secara optimal. Kelemahan lain kurangnya kemauan aparatur berbagi pengetahuan meskipun sudah mengikuti pendidikan, pelatihan maupun berbagai pengalaman lain. Rotasi aparatur antar tugas/jabatan dalam satu unit kerja kurang dilakukan. Kondisi-kondisi ini menyebabkan kematangan pribadi aparatur kurang dapat diwujudkan.

Kedua, model mental aparatur pada Pemerintah Kota Malang masih rendah. Rendahnya model mental aparatur ini dilihat dari pemaknaan terhadap pekerjaan. Walaupun sebagian aparatur telah menyadari bahwa pekerjaan dipandang sebagai profesi aparatur pemerintah yang mesti dijalankan dengan baik, karena dimaknai sebagai tugas kewajiban yang harus dilaksanakan semaksimal, akan tetapi juga masih terdapat aparatur yang menilai atau memandang pekerjaan sebagai tugas yang diberikan pimpinan untuk dilaksanakan sesuai perintah, sekaligus sebagai alat atau sarana pemenuhan kebutuhan hidup atau kepentingan dirinya. Ini menunjukkan bahwa aparatur belum menyadari makna dari hakikat kerja sebagai amanah dan kewajibannya.

Indikator lain dari disiplin model mental aparatur yang diteliti adalah proses berbagi value melalui dialog. Pemerintah Kota Malang telah menerapkan dialog yang bersifat formal yakni melalui rapat-rapat staf, rapat koordinasi, dan atau pertemuan rutin setiap bulan, serta apel pagi. Namun dialog tersebut dinilai belum efektif menyatukan nilai-nilai diantara aparatur, karena dalam rapat staf lebih bersifat pengarahan atau pembinaan pimpinan/atasan daripada penggalian atau pengungkapan nilai-nilai yang bermakna dalam diri aparatur melalui pemberian kesempatan secara bebas dan terbuka. Di sisi lain mekanisme dialog tidak didesain 
untuk terarahnya proses dialog melainkan dilakukan secara tiba-tiba atas kehendak atasan atau pimpinan. Selanjutnya, indikator lain yang menunjukkan belum baiknya model mental aparatur adalah adanya aparatur pemerintah yang melakukan pelanggaran disiplin sehingga diberikan sanksi sesuai ketentuan perundangan yang berlaku.

Ketiga, berkaitan dengan tim pembelajar, Pemerintah Kota Malang telah membentuk kelompok belajar berupa kelompok budaya kerja. Tim ini bertugas untuk mengidentifikasi dan membahas berbagai persoalan organisasi, serta memberikan rekomendasi. Dalam pelaksanaannya, tim pembelajar belum berjalan efektif dan mengalami beberapa hambatan, diantaranya koordinasi, komunikasi, serta pengawasan atasan. Hambatan inilah menyebabkan kelompok belajar pada sebagian satuan kerja Pemerintah Kota Malang belum berjalan efektif. Kelemahan lain adalah tim pembelajar tidak mensosialisasikan hasil kerjanya melainkan hanya merekomendasikan secara tertulis kepada pimpinan. Hambatan-hambatan tersebut membuat kerja aparatur kurang lancar, transfer pengetahuan secara kolektif terganggu, berbagi visi kurang berjalan dengan baik, dan pembentukan model mental kurang terlaksana. Implikasi lebih jauh membuat kualitas dan efektivitas kerja para aparatur menjadi kurang terwujud secara optimal.

Mengacu pada hasil penelitian, maka aplikasi organisasi pembelajar dalam rangka pengembangan sumberdaya aparatur untuk peningkatan kinerja pada Pemerintah Kota Malang belum efektif. Hal tersebut disebabkan beberapa faktor, antara lain motivasi dan kemampuan aparatur untuk mengembangkan diri masih rendah. Pola pemberdayaan aparatur dinilai belum optimal. Infrastruktur pembelajaran belum memadai, menyebabkan proses mendapatkan informasi atau pengetahuan menjadi terhambat. Di samping itu, budaya dan relasional belajar belum terbentuk. Hal ini menyebabkan proses berbagi pengetahuan, model mental, visi bersama dan belajar bersama kurang dapat diciptakan. Selanjutnya, kolaborasi dan kolegilitas belum tumbuh dengan baik.

Untuk itu diperlukan mekanisme yang baik agar implementasi organisasi pembelajar pada pemeritahan daerah dapat dilakukan dengan optimal. Mekanisme tersebut yaitu menciptakan komunikasi yang harmonis secara vertikal dan horizontal yang dapat membangun rasa saling percaya dan terbuka. Dengan tumbuhnya suasana seperti ini akan dapat menguatkan proses transformasi pengetahuan yang merupakan dasar dari organisasi pembelajar. Selain itu harus didukung penerapan sistem penghargaan yang mengakui prestasi anggota organisasi. Penataan struktur organisasi yang efektif untuk mempercepat proses berbagi pengetahuan, model mental, dan shared vision. Aplikasi organisasi pembelajar dapat berjalan baik harus diperkuat juga oleh sistem teknologi informasi yang dapat menunjang terciptanya aliran komunikasi atau alur informasi guna memperbesar kapasitas aparatur pemerintah.

Kebijakan Reformasi Birokrasi ini didasari oleh Peraturan Presiden Nomor 81 Tahun 2010 tentang Grand Design Reformasi Birokrasi Nasional 2010-2025, didalam nya mencakup 8 program/area perubahan salah satunya adalah program penataan dan penguatan organisasi dan program penataan tata laksana, dalam perpres ini juga dijelaskan 3 periode reformasi birokrasi yaitu 2010-2015, 20152020, 2020-2025.

Dalam periode pertama 2010-2015 didapatkan hasil penilaian sebesar $45 \%$, tahun berikutnya di dapat nilai $49 \%$, dan 
pada evaluasi terakhir untuk program penataan dan penguatan organisasi dan penataan tata laksana pada tahun 2017 didapatkan nilai 2,82 dari maksimal 6,00 untuk program penataan dan penguatan organisasi dan nilai 3,63 dari maksimal 5,00 untuk program penataan tata laksana.

\section{UCAPAN TERIMA KASIH}

Ucapan terima kasih disampaikan kepada. Prof. Dr. Bambang Supriyono. MS selaku Dekan FIA UB dan Dr. Mohammad Nuh, Sip,MSi selaku Ketua BPP - FIA UB.

\section{DAFTAR PUSTAKA}

Agun Gunandjar. 2012. Urgensi Reformasi Birokrasi. Pusat Dokumentasi Dan Informasi Hukum Nasional : Media Indonesia

Asep Muhammad. 2018. Memahami Reformasi Birokrasi. Pusat Teknologi Informasi dan Komunikasi Perhubungan (dephub.go.id))

Badan Kepegawaian Daerah Kota Malang, 2017/2018. Komposisi SDM Aparatur Kota Malang berdasarkan golongan, pendidikan, eselon, jenis kelamin, dan agama

Bambang Sunggono. 2001. Metodologi Penelitian Hukum. Rajawali Pers Effendi. Jakarta

BKD Kota Malang, 2018. Jumlah PNS/ ASN berdasarkan unit kerja s/d Desember 2018

BKD Kota Malang, 2018/2019. APBD Kota Malang untuk diklat struktural, teknis fungsional, ujian kenaikan pangkat/dinas 2018-2019

Fajar, M. dan Y. Achmad. 2010. Dualisme Penelitian Hukum Normatif dan Empiris.. Pustaka Pelajar. Yogyakarta

Haryanto (C1A1 13 027). 2017. Pelaksanaan Fungsi Pengawasan dalam Meningkatkan Efektivitas Kerja Pegawai Sekretariat Daerah Kota Kendari. Jurusan
Administrasi Negara. Fakultas Ilmu Administrasi. Universitas Halu Oleo

Muhammad Amir. 2015. Reformasi Birokrasi Perspektif Neo Weberian State, Teori, Konsep dan Aplikasi. Jenggala Pustaka Utama. Surabaya

Mustafa Delly. 2013. Birokrasi Pemertintahan. Alfabeta. Bandung

R. Koesoemahatmadja Etty Utju. 2011. "HUKUM KORPORASI" Penegakan HukumTerhadap Pelaku Economic Crimes dan Perlindungan Abuse of Power. Ghalia Indonesia. Bogor

Saldaña, Johnny. 2013. The coding manual for qualitative researchers. SAGE Publications. Los Angeles

Sedarmayanti. 2012. GOOD GOVERNANCE "Kepemerintahan Yang Baik" \& GOOD CORPORATE GVERNANCE "Tata Kelola Perusahaan yang Baik". CV. Mandar Maju. Bandung.

Tauda A. Gunawan. 2012. Komisi Negara Independen "Eksistensi Independent Agencies sebagai Cabang Kekuasaan Baru dalam Sistem Ketatanegaraan. Yogyakarta. 